\begin{tabular}{ll}
\hline & Jurnal Sains Materi Indonesia \\
Homepage: http:/jusami.batan.go.id & $\begin{array}{l}\text { Akreditation No:21/E/KPT/2018 } \\
\text { Date 9 July 2018 } \\
\text { ISSN 1411-1098 } \\
\text { E-ISSN 2614-087X }\end{array}$ \\
\hline
\end{tabular}

\title{
THE EFFECT OF CALCINATION ON MICROWAVE ABSORBING PROPERTIES OF $\mathrm{Fe}_{3} \mathrm{O}_{4} / \mathrm{TiO}_{2}$ COMPOSITE
}

\author{
Adel Fisli ${ }^{1}$, Didin S. Winatapura ${ }^{1}$, Wisnu Ari Adi ${ }^{1}$, Yana Taryana ${ }^{2}$ \\ ${ }^{I}$ Center for Science and Technology of Advanced Materials- National Nuclear Energy Agency, Kawasan \\ Puspiptek Serpong, Tangerang Selatan, Banten, Indonesia \\ ${ }^{2}$ Research Center for Electronics and Telecommunication, Indonesian Institute of Sciences, Bandung, West Java, \\ Indonesia
}

Email:adel@batan.go.id

Received: 10 September $2018 \quad$ Revised: 11 December $2018 \quad$ Accepted: 18 December 2018

\begin{abstract}
THE EFFECT OF CALCINATION ON MICROWAVE ABSORBING PROPERTIES OF $\mathrm{Fe}_{3} \mathrm{O}_{4} / \mathrm{TiO}_{2}$ COMPOSITE. The $\mathrm{Fe}_{3} \mathrm{O}_{4} / \mathrm{TiO}_{2}$ composites have been fabricated by simple precipitation method for microwave absorbing. The obtained powder of $\mathrm{Fe}_{3} \mathrm{O}_{4} / \mathrm{TiO}_{2}$ which $10 \%$ iron oxide containing were calcinated from $300^{\circ} \mathrm{C}-700^{\circ} \mathrm{C}$ for 3 hours. The characteristic of samples was investigated by various techniques. The TEM image showed the composites form agglomeration with particles size of around $20 \mathrm{~nm}$. The all sample contents most of the anatase phase. The increasing of calcination temperature is the bigger of crystallite size. The Raman bands shift towards lower wavenumber and their full-widths at half-maximum (FWHM) of the bands decreases as the particles size increase. The measurement of the magnetic properties illustrated that the $\mathrm{Fe}_{3} \mathrm{O}_{4} / \mathrm{TiO}_{2}$ exhibited paramagnetic behavior at room temperature. The microwave absorbing properties of the sample was measured by VNA using frequency microwave filter in X-band range (8-12 GHz). The reflection loss (RL) values were calculated for thickness $1 \mathrm{~mm}$ of the sample. The minimum reflectivity peak value tends to decrease with the increase of the calcination temperature due to increasing the crystallite size of the particles. The lowest reflectivity value of $\mathrm{Fe}_{3} \mathrm{O}_{4} / \mathrm{TiO}_{2}$ was occurred calcinated at $600^{\circ} \mathrm{C}$ with $-13.4 \mathrm{~dB}$ loss at $10.9 \mathrm{GHz}$, that is more $80 \%$ absorbed of the electromagnetic wave in thickness $1 \mathrm{~mm}$ of the sample. The microwave absorption properties the calcinated $700^{\circ} \mathrm{C}$ the sample decrease due to the loss of magnetic properties of the sample. This study concluded that increase in average crystalline size, microwave absorption properties increased. However, the decrease drastically of magnetic properties of the sample causes microwave absorption properties to decrease.
\end{abstract}

Keywords: RAM (radar absorbing material), composite, titanium, magnetite, calcination effect.

\begin{abstract}
ABSTRAK
PENGARUH KALSINASI TERHADAP SIFAT SERAPAN GELOMBANG MIKRO KOMPOSIT Fe $\mathrm{O}_{4} / \mathrm{TiO}_{2}$. Komposit $\mathrm{Fe}_{3} \mathrm{O}_{4} / \mathrm{TiO}_{2}$ telah berhasil dibuat dengan metode presipitasi sederhana untuk menyerap gelombang mikro. Serbuk $\mathrm{Fe}_{3} \mathrm{O}_{4} / \mathrm{TiO}_{2}$ yang diperoleh (mengandung $10 \%$ oksida besi) dikalsinasi dari suhu $300^{\circ} \mathrm{C}-700^{\circ} \mathrm{C}$ selama 3 jam. Karakteristik sampel diselidiki dengan berbagai teknik. Foto TEM menunjukkan bahwa komposit membentuk aglomerasi dengan ukuran partikel sekitar $20 \mathrm{~nm}$. Semua sampel mengandung fase anatase. Semakin meningkat suhu kalsinasi maka ukuran kristalin juga meningkat. Pita Raman bergeser ke arah bilangan gelombang rendah dan juga full-widths at half-maximum (FWHM) semakin sempit menandakan ukuran kristalin meningkat dengan meningkatnya suhu. Komposit $\mathrm{Fe}_{3} \mathrm{O}_{4} / \mathrm{TiO}_{2}$ memperlihatkan perilaku paramagnetik pada suhu kamar. Sifat serapan gelombang mikro sampel diukur dengan alat VNA dalam rentang frekuensi gelombang X-band (8-12 GHz) pada ketebalan sampel $1 \mathrm{~mm}$. Nilai reflection loss $\left(R_{F}\right)$ cenderung menurun dengan meningkatnya suhu kalsinasi karena meningkatnya ukuran kristal partikel. Nilai reflection loss terendah (terbaik) terjadi pada suhu kalsinasi $600^{\circ} \mathrm{C}$ dengan $-13,4 \mathrm{~dB}$ pada frekuensi $10,9 \mathrm{GHz}$, artinya lebih $80 \%$ gelombang elektromagnetik diserap pada ketebalan sampel $1 \mathrm{~mm}$. Sifat serapan gelombang mikro pada $700^{\circ} \mathrm{C}$ berkurang karena hilangnya sifat magnetik bahan. Studi ini disimpulkan bahwa semakin besar ukuran kristal maka sifat serapan gelombang mikro bahan juga meningkat. Namun demikian, penurunan dratis sifat magnetik bahan menyebabkan sifat serapan gelombang mikro sampel juga menurun.
\end{abstract}

Kata kunci: RAM (Radar Absorbing Material), Komposit, Titanium, Magnetite, Efek kalsinasi 


\section{INTRODUCTION}

A radar-absorbing material (RAM) diminishes the stage of electromagnetic energy reflected, or scattered, from its surface [1]. It has been applied as in equipment electromagnetic shielding employed in automotive and aerospace industries, military technology, electrical and electronic devices and systems for wireless communication [2]. The excellent of radar absorbing material (RAM) should have high absorption, broadband and intend light quality performance [3]. The materials are classified into two types, according to their interactions with the electromagnetic wave: materials with dielectric losses, which interact with the electric wave field, and materials with magnetic losses, which interact with the wave magnetic field. Therefore, the dielectric and magnetic materials are the focus of extensive study for microwave absorbers [2].

The absorption behavior of electromagneticabsorber interaction mainly depends on the dielectric properties of the absorber and the amount of absorption which can be expressed by reflection loss (RL). The value of $R L$ is defined as:

$$
R L=-20 \log \left|\frac{Z_{\text {in }}-Z_{o}}{Z_{\text {in }}-Z_{o}}\right|
$$

where $Z_{\text {in }}$ is the impedance of absorbing materials and Zo is the impedance of free space. The impedance of absorbing material (Zin) depended on the complex permittivity and complex permeability of the absorbing material and defined as:

$$
Z_{\text {in }}=Z_{o} \sqrt{\left(\frac{\mu_{r}}{\varepsilon_{r}}\right)} \tanh \left\{j\left(\frac{2 \pi f d}{c}\right) \cdot \sqrt{\left(\mu_{r} \varepsilon_{r}\right)}\right\}
$$

where $\mu \mathrm{r}$ and $\varepsilon r$ are the complex permeability and permittivity of the composite materials, $\mathrm{f}$ is the working frequency, $\mathrm{d}$ is the thickness of the microwave absorber, and $\mathrm{c}$ is the velocity of light. Base on equations 1 and 2 that the value of RL depends on the complex permittivity, complex permeability, thickness of absorber and working frequency [4].

Titania is known to apply to a range of beneficial technological areas as a white pigment in the various material industry and photocatalyst [5]. The titanium oxide $\mathrm{TiO}_{2}$ as the stable dielectric material is also useful material for electromagnetic wave absorption. Few articles concerning the microwave absorbing properties of $\mathrm{TiO}_{2}$-based composites have been reported such as titanium oxide and rubber composite [6] doped barium hexaferrite/ $\mathrm{TiO}_{2} /$ conducting carbon black [7], chlorinated polyethylene/ $\mathrm{TiO}_{2}$ [8] $\mathrm{MnFe}_{2} \mathrm{O}_{4} / \mathrm{TiO}_{2}$ nanocomposite [9], metal dispersed $\mathrm{TiO}_{2}$ nanocomposite [10]. The composite of $\mathrm{TiO}_{2}$ and iron oxide is a better match for the dielectric loss, and magnetic loss may be realized. $\mathrm{Zhu}$ et al. (2010) [11] reported that $\mathrm{Fe}_{3} \mathrm{O}_{4} / \mathrm{TiO}_{2}$ core/shell nanotubes for electromagnetic wave absorption were fabricated through a three-step process, e.i. Hydrothermal method, a wet-chemical method and calcination process under a mixture of $\mathrm{Ar} / \mathrm{H}_{2}$ flow. The maximum reflection loss of the material reaches -20.6 84
$\mathrm{dB}$ at $17.28 \mathrm{GHz}$ for the absorber with a thickness of 5 $\mathrm{mm}$.

Beside of the material composition, The morphology and particles size play very important role in absorbing behavior. The increasing of crystalline size does shift not only the position of reflection loss toward higher frequency region but also lower the minimum reflection loss [12]. The calcination can strongly affect on the particles size, morphology and magnetic properties [13]. Kumar et al.,(2013) [14] reported that the particles size had significant influence on the dielectric and absorption properties of the material. The complex dielectric properties, loss targets, reflection loss and bandwidth increase with the increase in average particles size.

Previous work, the effect of $\mathrm{Fe}^{2+}$ and $\mathrm{Fe}^{3+}$ substitution on the crystal structure, optical and magnetic properties of anatase $\mathrm{Ti}_{1-\delta}\left(\delta \% \mathrm{Fe}^{2+}\right) \mathrm{O}_{2}$ nanoparticles at $500^{\circ} \mathrm{C}$ in calcinations temperature has been studied. Up to $5 \%$ of either $\mathrm{Fe}^{2+}$ or $\mathrm{Fe}^{3+}$ successfully substituted into $\mathrm{Ti}^{4+}$ without changing the crystal structure of titania [15]. The effect of particles size on microwave absorption is very less attention in the literature. The particles size value and particles morphology are depended at calcination step. Therefore, this paper is intended as an investigation of preparation of the titania-magnetite by simple precipitation method. They were grown in size by increasing the calcination temperature step at 300 , $400,500,600$ and $700^{\circ} \mathrm{C}$ under atmosphere condition. The investigated materials are discussed includes; morphology, phase and crystallite size analysis, chemical bonding, magnetic properties and microwave absorption properties at X-band.

\section{EXPERIMENTAL METHOD}

\section{Materials}

Chemical including Iron (III) chloride hexahydrate $\left(\mathrm{FeCl}_{3} .6 \mathrm{H}_{2} \mathrm{O}\right)$, Iron (II) chloride tetrahydrate $\left(\mathrm{FeCl}_{2} .4 \mathrm{H}_{2} \mathrm{O}\right)$, Titanium tetrachloride $\left(\mathrm{TiCl}_{4}\right)$ 98\%, Ammonia $25 \%$, Hydrochloride $(\mathrm{HCl})$ were analytical grade (Merck) and were used without further purification.

\section{Preparation of $\mathrm{TiO}_{2} / \mathrm{Fe}_{3} \mathrm{O}_{4}$}

The solution of $0.3 \mathrm{M} \mathrm{TiCl}_{4}$ was prepared from Titanium tetrachloride $\left(\mathrm{TiCl}_{4}\right) 98 \%$ in distilled water in an ice-water bath. In another container, $5.2 \mathrm{~g}$ of $\mathrm{FeCl}_{3} .6 \mathrm{H}_{2} \mathrm{O}$ and $2.0 \mathrm{~g}$ of $\mathrm{FeCl}_{2}$ were dissolved in $10 \mathrm{~mL}$ $\mathrm{HCl} 1 \mathrm{~N}$ under vigorous stirring and continued to add $15 \mathrm{~mL}$ distilled water. This mixture results in an aqueous solution with a molar ratio of $\mathrm{Fe}(\mathrm{II}) / \mathrm{Fe}(\mathrm{II})=0.5$. It is important to perform the $\mathrm{Fe}_{3} \mathrm{O}_{4}$ produce. The iron salts were mixed with $\mathrm{TiCl}_{4}$ solution under vigorous stirring at room temperature. The resulting solution was added drop into $250 \mathrm{~mL}$ of $1.5 \mathrm{NH}_{4} \mathrm{OH}$ solutions under vigorous stirring. The formed precipitate was isolated from supernatant by decantation process. Obtained solid was repeatedly washed until the $\mathrm{pH}$ solution of 
supernatant was neutral. The solid was dried in oven at $100^{\circ} \mathrm{C}$, further calcinated in furnace under atmosphere at $300^{\circ} \mathrm{C}, 400^{\circ} \mathrm{C}, 500^{\circ} \mathrm{C}, 600^{\circ} \mathrm{C}$ and $700^{\circ} \mathrm{C}$ for 3 hours.

\section{Characterization}

XRD patterns of the samples were recorded on an Empyrean Panalytical with $\mathrm{Cu}-\mathrm{K} \alpha$ radiation, $\lambda=1.154 \AA$ operation at $40 \mathrm{kV}$ and $30 \mathrm{~mA}$ for the $2 \theta$ range $10-80$ with scan steps of 0.02 . The average crystallite size according to the Debye-Scherrer formula using XRD data. The magnetic properties were measured by vibrating sample magnetometer (VSM-Oxford type $1.2 \mathrm{~T}$ ) at room temperature in the applied field rate 0.25 Tesla/minute, range from -1 to +1 Tesla. The morphology of the composite was examined by transmission electron microscopy (TEM, JEM-14000 JOEL). TEM sample was prepared by dispersing the sample in ethanol and dropping the suspension on a copper grid. Raman spectra were observed by a Raman spectrometer Bruker serial number 254 at radiation of $785 \mathrm{~nm}$ the power $1 \mathrm{~mW}$. The microwave absorption properties of the composite were calculated at room temperature using a microwave vector network analyzer (VNA-ADVANTEST R3770) with a frequency range from 8 to $12 \mathrm{GHz}$.

\section{RESULTS AND DISCUSSION}

Figure 1 shows the transmission electron microscopy (TEM) image of $\mathrm{TiO}_{2} / \mathrm{Fe}_{3} \mathrm{O}_{4}$ at $500^{\circ} \mathrm{C}$ calcination. It can clearly see that $\mathrm{TiO}_{2} / \mathrm{Fe}_{3} \mathrm{O}_{4}$ particles are spherical form. It is obvious from this image that the $\mathrm{TiO}_{2} / \mathrm{Fe}_{3} \mathrm{O}_{4}$ particles are dispersed with around particle size of $20 \mathrm{~nm}$ with agglomeration form. The particles size of samples from the TEM images are in good agreement with the value obtained by applying the Scherrer equation to the XRD patterns.

Figure 2 show XRD patterns for calcinated variant of $\mathrm{TiO}_{2} / \mathrm{Fe}_{3} \mathrm{O}_{4}$ powder from $300^{\circ} \mathrm{C}$ to $700^{\circ} \mathrm{C}$. The peaks appear at $2 \theta=25.4^{\circ} ; 37.9^{\circ} ; 48.1^{\circ} ; 53.40$; $55.9^{\circ} ; 62.8^{\circ}$; and $75.1^{\circ}$. All peaks are agreement with the standard spectrum JCPDS no. 21-1272) which are well indexed to the anatase phase (101), (004), (200), (105), (211), (118), and (220), respectively. Especially, for calcinated $700^{\circ} \mathrm{C}$ of the sample appeared the new diffraction at $27.24^{\circ}$ and $32.36^{\circ}$ which are denoted to rutile and illmenite phase, respectively. Hanaor et al. (2011) [5] reported that the anatase to rutile transformation is not immediately which it need time for reconstruction. The pure bulk anatase is considered widely begin to transform irreversibly to rutile in air at $600^{\circ} \mathrm{C}$. Actually, the transition temperature can occur in the range $400-1200^{\circ} \mathrm{C}$. The average crystallite diameter (ACD) of the $\mathrm{TiO}_{2}$ particles was determined from the major diffraction peak (101) using the well-known Scherrer's formula.

$$
A C D=\frac{K \lambda}{\beta \cos \theta}
$$

where $\mathrm{K}$ is the Scherrer constant, $\lambda$ is the $\mathrm{X}$-ray wavelength, $\theta$ is the angle of Bragg diffraction, and $\beta$ is the difference between the full-width at half-maximum (FWHM) which has been corrected by the instrumental broadening. The average particles sizes observed at different sintering conditions are given in Table 1 . The calculated ACD value of nanocrystalline $\mathrm{TiO}_{2} / \mathrm{Fe}_{3} \mathrm{O}_{4}$ variation is found in range $7.25-30.14 \mathrm{~nm}$. This value is in agreement with the result of TEM investigation. The increasing of calcination temperature is the bigger of crystallite size. The results indicate that the particles size growth under the influence of sintering. Evidently, the sintering temperature promotes enlargement of grain boundaries and consequently particles size increases as a function of sintering temperature.

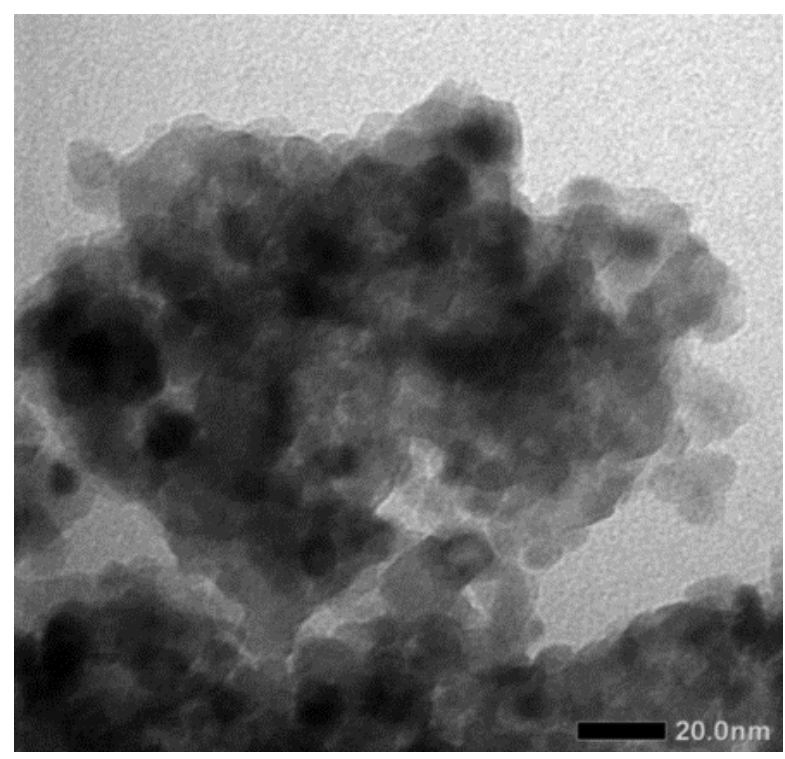

Figure 1. TEM images of $\mathrm{TiO}_{2} / \mathrm{Fe}_{3} \mathrm{O}_{4}$ powder at $500^{\circ} \mathrm{C}$ calcinations, representative.

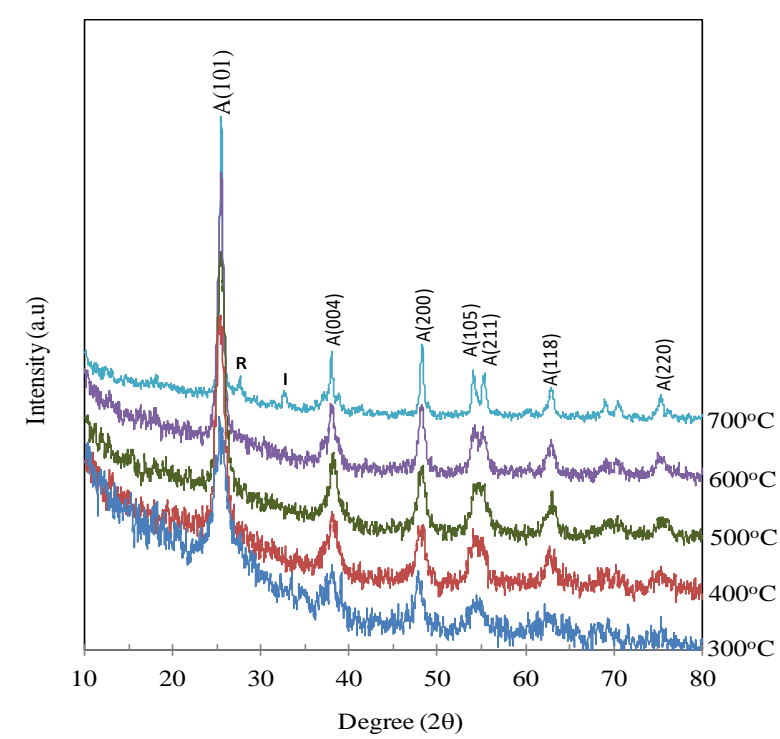

Figure 2. $\mathrm{XRD}$ pattern of $\mathrm{Fe}_{3} \mathrm{O}_{4} / \mathrm{TiO}_{2}$ powder annealed from $300^{\circ} \mathrm{C}$ to $700^{\circ} \mathrm{C}$ for 3 hours, $\mathrm{A}=$ anatase, $\mathrm{R}=$ Rutile, and $\mathrm{I}=$ Ilmenite 
Table 1. The crystalline size and $\mathrm{E}_{\mathrm{g}}$ Raman active modes values for annealed samples

\begin{tabular}{ccccc}
\hline No & $\begin{array}{c}\text { Calcination } \\
\text { temperature }\end{array}$ & $\begin{array}{c}\text { Crystalline } \\
\text { size } \\
(\mathrm{nm})\end{array}$ & $\begin{array}{c}\text { E } \mathrm{g} \text { Raman active } \\
\text { modes } \\
\left(\mathrm{cm}^{-1}\right) \\
\text { FWHM }\end{array}$ \\
$\begin{array}{ccccc}\mathrm{E}_{\mathrm{g}} \\
\mathrm{FWH}\end{array}$ \\
\hline 1 & $300^{\circ} \mathrm{C}$ & 7.25 & 25.24 & 151 \\
2 & $400^{\circ} \mathrm{C}$ & 9.59 & 18.99 & 147 \\
3 & $500^{\circ} \mathrm{C}$ & 10.77 & 16.71 & 146 \\
4 & $600^{\circ} \mathrm{C}$ & 14.63 & 14.76 & 145 \\
5 & $700^{\circ} \mathrm{C}$ & 30.14 & 12.91 & 144 \\
\hline
\end{tabular}

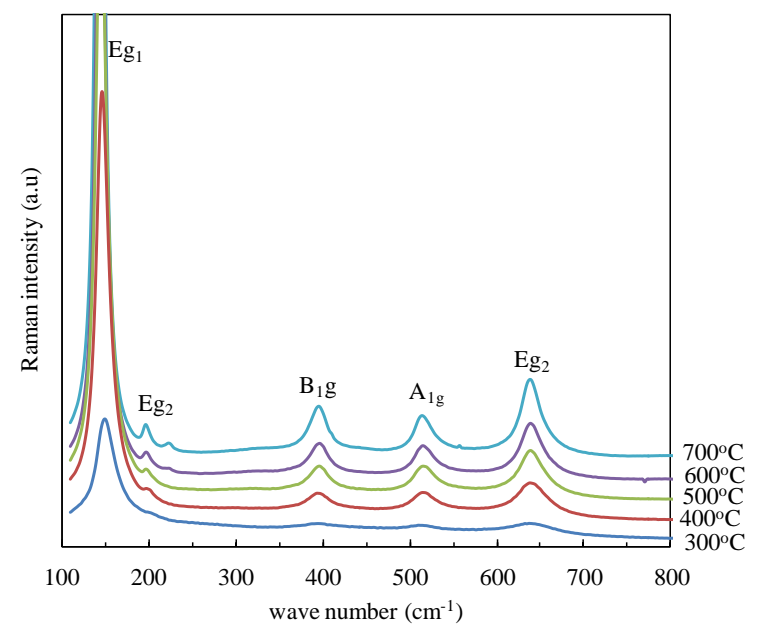

Figure 3. Raman spectra of $\mathrm{Fe}_{3} \mathrm{O}_{4} / \mathrm{TiO}_{2}$ powder annealed from $300^{\circ} \mathrm{C}$ to $700^{\circ} \mathrm{C}$ for 3 hours.

$\mathrm{TiO}_{2}$ nanoparticles have frequently been investigated with Raman spectroscopy. Based on the space group D4h for anatase and assumed site symmetries for the $\mathrm{TiO}$ and $\mathrm{O}$ atoms within the unit cell $\left(\mathrm{D}_{2} \mathrm{~d}\right.$ for $\mathrm{Ti} ; \mathrm{C}_{2} \mathrm{v}$ for $\left.\mathrm{O}\right)$ shows six Raman active modes $\left(\mathrm{A}_{1} \mathrm{~g}\right.$, $2 \mathrm{~B}_{1} \mathrm{~g}$, and $3 \mathrm{Eg}$ ). Osaka has explained that the Raman spectrum of an anatase single has six modes such as at $144 \mathrm{~cm}^{-1}(\mathrm{Eg}), 197 \mathrm{~cm}^{-1}(\mathrm{Eg}), 399 \mathrm{~cm}^{-1}\left(\mathrm{~B}_{1} \mathrm{~g}\right), 513 \mathrm{~cm}^{-1}$ (A1g), $519 \mathrm{~cm}^{-1}$, and $639 \mathrm{~cm}^{-1}(\mathrm{Eg})$ [16]. The observed Raman bands at $639 \mathrm{~cm}^{-1}, 519 \mathrm{~cm}^{-1}$, and $399 \mathrm{~cm}^{-1}$ are consistent with the moderately distorted $\mathrm{TiO}_{6}{ }^{8-}$ octahedron in anatase. The sharp peaks at $197 \mathrm{~cm}^{-1}$ and 144 $\mathrm{cm}^{-1}$ are consistent with Ti-Ti bonding present at the octahedral chains [17]. In this study in Figure 3, the obtained Raman bands of varied samples are in the range of $151-144 \mathrm{~cm}^{-1}(\mathrm{Eg}), 196-197 \mathrm{~cm}^{-1}(\mathrm{Eg}), 394-396 \mathrm{~cm}^{-}$ ${ }^{1}$ (B1g), 510-515 cm-1 (A1g), and 637- $639 \mathrm{~cm}^{-1}(\mathrm{Eg})$. Based on analysis of the Raman band, we declare that the sample has anatase for all samples. The results agree with obtained XRD analysis. The change of $\mathrm{TiO} 2$ particles size can be known with studying of band broadening and shifts of Raman bands. It is clear seen that the Raman bands shift towards lower wavenumber and their full-widths at half-maximum (FWHM) of the bands decreases as the particles size increase (insert Figure 3). The Raman shifts are due to the effects of alteration of particles size on the force constants and vibrational amplitudes of the nearest neighbor bonds. While the broadening of Raman bands increases with 86 decreasing particles size. This broadening of the phonon momentum leads to broadening of the scattered phonon momentum [16].

The measured magnetic properties of $\mathrm{Fe}_{3} \mathrm{O}_{4} / \mathrm{TiO}_{2}$ samples annealed at different temperatures are shown in Figure 4. The measurement of the magnetic properties by VSM attributed that the $\mathrm{Fe}_{3} \mathrm{O}_{4} / \mathrm{TiO}_{2}$ exhibited paramagnetic behavior at room temperature. Inser Figure 4 shown the saturation magnetization versus calcination temperature of the samples. The sample was annealed from $100^{\circ} \mathrm{C}$ to $300^{\circ} \mathrm{C}$ shows that the saturation magnetization of sample increase with increasing of annealing temperature. However, further increasing of annealed temperature from $300^{\circ} \mathrm{C}$ to $600^{\circ} \mathrm{C}$ is occurred decreases gradually the saturation magnetization (Ms) value of the sample. The loss of Ms can be attributed to the transformation phase of iron oxide partially from magnetite $\left(\mathrm{Fe}_{3} \mathrm{O}_{4}\right)$ to maghemite $\left(\gamma-\mathrm{Fe}_{2} \mathrm{O}_{3}\right)$ [18]. Finally, saturation magnetization of the sample decreases drastically for annealing temperature of $700^{\circ} \mathrm{C}$. It can be assigned that maghemite $\left(\gamma-\mathrm{Fe}_{2} \mathrm{O}_{3}\right)$ undergoes phase transition into hematite $\left(\alpha-\mathrm{Fe}_{2} \mathrm{O}_{3}\right)$.

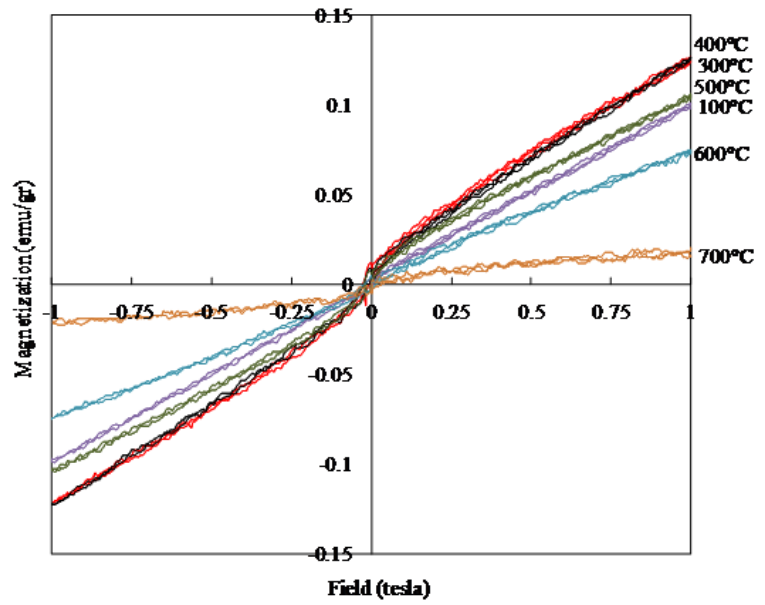

Figure 4. The saturation magnetization of $\mathrm{Fe}_{3} \mathrm{O}_{4} / \mathrm{TiO}_{2}$ powder annealed from $100^{\circ} \mathrm{C}$ to $700^{\circ} \mathrm{C}$ for 3 hours

The reflection loss of the samples in the $\mathrm{X}$ band range $(8-12 \mathrm{GHz})$ was shown in Figure 5. The thickness of sample for reflection loss (RF) measurement was about $1 \mathrm{~mm}$. The dips in the values of RL versus frequency imply low reflectivity (and good absorption). As we can see, the minimum reflectivity peak value tends to decrease with the increase of the annealing temperature from $300^{\circ} \mathrm{C}$ to $600^{\circ} \mathrm{C}$. It means that the absorption of electromagnetic wave increases with increasing annealing temperature. It due to increasing the particle size with increasing of annealing temperature, resulting in large dense particles (agglomerates). These results are in line with those reported by Costa et al. (2009) [19] that raising the calcination temperature increased the particle sizes of the powder, improving the reflectivity of the materials. The lowest value of reflection loss was obtained for annealed $600^{\circ} \mathrm{C}$ with RF 13,4 at $10.9 \mathrm{GHz}$. These results denoted that more $80 \%$ 
of electromagnetic wave absorbed on the sample. However, further reflection loss increases with annealed temperature at $700^{\circ} \mathrm{C}$. It is due to the decreasing magnetic properties of the material. Magnetic properties such as coercivity $(\mathrm{Hc})$ and saturation magnetization (Ms) can be improved when the grain size is reduced to nanoscale. Thus, the overall microwave absorption is a competition among dielectric properties, magnetic properties and structure of particles (grain/particles size and shape).

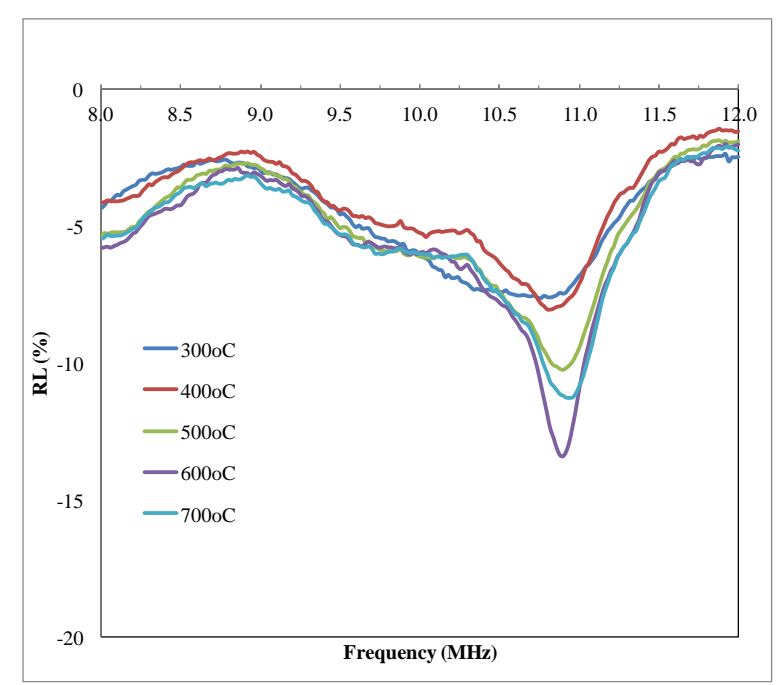

Figure 5. VNA measurement of $\mathrm{Fe}_{3} \mathrm{O}_{4} / \mathrm{TiO}_{2}$ powder annealed from $300^{\circ} \mathrm{C}$ to $700^{\circ} \mathrm{C}$ for 3 hours

\section{CONCLUSIONS}

The $\mathrm{Fe}_{3} \mathrm{O}_{4} / \mathrm{TiO}_{2}$ composite powder with different calcinated temperature has been successfully synthesized by simple precipitation method. The calcination temperature affects on the average crystallite size dan magnetic properties, which plays an important role in absorption of electromagnetic wave. Crystalline size increase and saturation decrease with increasing calcination temperature. Absorption of electromagnetic wave tends to increase with increasing crystallite size. However, the loss of magnetic properties of the sample will decrease the absorption of electromagnetic wave. The minimum RL value of $-13,4 \mathrm{~dB}$ is observed at $10.9 \mathrm{GHz}$ for calcinated $600^{\circ} \mathrm{C}$ of the sample with thickness of $1.00 \mathrm{~mm}$.

\section{ACKNOWLEDGMENT}

The authors are grateful for the support from Center for Science and Technology of Advanced Materials, National Nuclear Energy Agency, Government Research of the Republic of Indonesia. Financial support by Research and Development of Smart Magnetic Programs for DIPA 2016 grand is gratefully acknowledged.

\section{REFERENCES}

[1]. A. Tennant. "Radar-absorbing Materials”, University of Sheffield, UK, 2014.

[2]. V. L. Soethe, E. L. Nohara, L. C. Fontana, M. C. Rezende, "Radar absorbing materials based on titanium thin film obtained by sputtering technique", Journal of Aerospace Technology and Management, vol. 3 no. (3), pp. 279-286, 201.

[3]. H. Chongkang, P. Shunkang, C. Lichun, L. Xing, W. Yajun, "Effect of rare earth on microwave absorbing properties of RE-Co alloys", Journal of Rare Earths, vol. 33, no. 3), pp. 271-277, 2015.

[4]. V. L. Soethe, E. L. Nohara, L. C. Fontana, M. C. Rezende, "Radar absorbing materials based on titanium thin film obtained by sputtering technique", Journal of Aerospace Technology and Management, vol. 3, no. 3, pp. 279-286, 2011.

[5]. H. Hajimiri, M. S. S. Dorraji, M. H. Rasoulifard, A. R. Amani-Ghadim, M. R. Khoshroo, "Combination of perovskite and magnetic inverse spinel structures to improve microwave absorption properties", Materials Science and Engineering B, vol. 225, pp. 75-85, 2017.

[6]. D. A. H. Hanaor, C. C. Sorrell, "Review of the anatase to rutile phase transformation". Journal Materilas Science, vol. 46, pp. 855-874, 2011.

[7]. Y. J. An, H. Okino, T. Yamamoto, S. Ueda, T. Deguchi, "Microwave dielectric properties of lossy dielectric composite material", Japanese Journal of Applied Physics, vol. 45, no. 9B, 2006.

[8]. C. M. Choi, K. S. Ko, “A study on absorption properties of the EM wave absorber using $\mathrm{TiO}_{2}$ in WBand". Journal of Navigation and Port Research International Edition, vol. 34, no 2, pp. 111-115, 2010.

[9]. H. M. Xiao, X. M. Liu, S. Y. Fu, "Synthesis, magntic and microwave absorbing properties of core-shell structured $\mathrm{MnFe}_{2} \mathrm{O}_{4} / \mathrm{TiO}_{2}$ nanocomposites". Composites Science and Technology, vol. 66, pp. 2003-2006, 2006.

[10]. A. Kumar, V. Agarwala, D. Singh, "Microwave absorbing behavior of metal dispersed $\mathrm{TiO}_{2}$ nanocomposites", Advanced Power Technology, vol. 25, pp. 483-489, 2014.

[11]. C. L. Zhu, M. L. Zhang, Y. J. Qiao, G. Xiao, F. Zhang, Y. J. Chen, " $\mathrm{Fe}_{3} \mathrm{O}_{4} / \mathrm{TiO}_{2}$ core/shell nanotubes: synthesis and magnetic and electromagnetic wave absorption characteritics", Journal of Physic Chemistry C, vol. 114, pp. 16229-16235, 2010.

[12]. Y. Wang, T. Li, L. Zhao, Z. Hu, Y. Gu, "Research progress on nanostructure radar absorbing material", Energy and Power Engineering, vol. 3, pp. 580-584, 2011.

[13]. Y. Qu, H. Yang, N. Yang, Y. Fan, H. Zhu, G. Zou, "The effect of reaction temperature on the particle size, structure and magnetic properties of coprecipitated $\mathrm{CoFe}_{2} \mathrm{O}_{4}$ nanoparticles", Materials Letters, vol. 60, pp. 3548-3552, 2006.

[14]. A. Kumar, V. Agarwala, D. Singh, "Effect of particles size of $\mathrm{BaFe}_{12} \mathrm{O}_{19}$ on the microwave 
absorption characteristics in X-band", Progress in Electromagnetic Research M, vol. 29, pp. 223-236, 2013.

[15]. W. A. Adi, A. Fisli, "Efek substitusi $\mathrm{Fe}^{2+}$ dan $\mathrm{Fe}^{3+}$ terhadap struktur Kristal, sifat optik dan magnetik pada nanopartikel anatase $\mathrm{Ti}_{1-\delta}\left(\delta \% \mathrm{Fe}^{2+}\right) \mathrm{O}_{2} "$, Jurnal Sains Materi Indonesia, Vol. 19 No 2, pp. 54-60, 2018

[16]. H. C. Choi, Y. M. Jung, S. B. Kim, "Size effect in the Raman spectra of TiO2 nanoparticles", Vibrational Spectroscopy, vol. 37, pp. 33-38, 2005.

[17]. F. D. Hardcastle, "Raman spectroscopy of titania $\left(\mathrm{TiO}_{2}\right)$ nanotubular water-splitting catalysts", Journal of the Arkansas Academy of Science, vol. 65, pp. 43-48, 2011.
[18]. A. Sutka, S. Lagzdina, T. Kambre, P. Parna, V. Kisand, J. Kleperis, M. Maiorov, A. Kikas, I. Kuusik, D. Jakovlevs, "Study of the structure phase transformation of iron oxide nanoparticles from an $\mathrm{Fe}^{2+}$ ion source by precipitation under various synthesis parameter and temperature". Materials Chemistry and Physic, vol. 149, pp. 473-479, 2015. [19]. A. C. F. M. Costa, A. P. Diniz, V. J. Silva, R. H. G. A, Kiminami, D. R. Carnejo, A. M. Gama, M. C. Rezende, L. Gama, "Influence of calcination temperature on the morphology and magnetic properties of Ni-Zn ferrite applied as an electromagnetic energy absorber", Journal of Alloys and Compounds, 483, 563-565, 2009.

Copyright (c) 2019 Jusami | Indonesian Journal of Materials Science. This article is an open access article distributed under the terms and conditions of the Creative Commons Attribution-NonCommercial-ShareAlike 4.0 International License (CC BY-NC-SA 4.0). 